\title{
CALIBRATION OF THE RISING PLATE METER FOR MIXED PASTURES OF RYEGRASS (Lolium perenne L.) AND KIKUYO (Cenchrus clandestinus)
}

\author{
Javier Cárdenas ${ }^{1}$, Oscar Balocchi ${ }^{2}$, Iván Calvache ${ }^{2 *}$ \\ ${ }^{1}$ Programa de Zootecnia, Facultad de Ciencias Agropecuarias, Universidad de La Salle, ZIP, 110221117, \\ Bogotá, Colombia. \\ ${ }^{2}$ Instituto de Producción Animal, Facultad de Ciencias Agrarias, Universidad Austral de Chile, PO Box \\ 567, 5090000, Valdivia, Chile. \\ *Corresponding author E-mail: ivan.calvache@uach.cl
}

\begin{abstract}
Accumulated herbage mass (AHM) availability is a determining criterion for efficient pasture management and use. The Rising Plate Meter (RPM) is a tool for estimating this parameter; to do so, equations need to be developed for the pasture conditions in which it will be used. The objective of this study was to develop a calibration equation for the RPM to determine AHM in mixed pastures of Lolium perenne L. and Cenchrus clandestinus. The experiment was carried out at the San Pedro farm located in the municipality of Cota, Cundinamarca Department, Colombia. Sixteen experimental paddocks were used, composed of $30 \% \mathrm{~L}$. perenne and $70 \% \mathrm{C}$. clandestinus; 25 samples per paddock were taken on a daily basis throughout the experimental period. A linear regression analysis was performed for compressed height $(\mathrm{CH})$ and AHM expressed in $\mathrm{kg} \mathrm{DM} \mathrm{ha}^{-1}$. The resulting equation for the RPM calibration showed a high level of precision and indicated that AHM (kg ha-1) is highly dependent on $\mathrm{CH}$. Given the level of accuracy of the regression equation developed in this study $\left(R^{2}=0.85\right)$, the RPM can be a useful tool for estimating AHM at a field level for mixed grasslands composed of L. perenne and C. clandestinus.
\end{abstract}

Key words: Linear regression, accumulated herbage mass, compressed height, forage mass available.

\section{RESUMEN}

La acumulación de materia seca (AMS) disponible es un criterio determinante para el eficiente uso y manejo de la pradera. El plato medidor de praderas (PMP) es una herramienta disponible para estimar este parámetro; para esto, es necesario desarrollar ecuaciones para las condiciones de la pradera donde será utilizado. El objetivo de este estudio fue desarrollar una ecuación de calibración para determinar AMS en praderas mixtas compuestas por Lolium perenne L. y Cenchrus clandestinus con el PMP. El experimento se realizó en la finca San Pedro ubicada en el municipio de Cota, departamento de Cundinamarca, Colombia. Diez y seis potreros experimentales fueron usados, compuestos de $30 \%$ L. perenne y $70 \%$ C. clandestinum, y 25 muestras fueron tomadas diariamente durante el periodo experimental por cada potrero. Un análisis de regresión lineal fue corrido entre altura comprimida (AC) y MSA expresada en $\mathrm{kg} \mathrm{MS} \mathrm{ha-1}^{-1}$. El resultado de la ecuación de calibración para el PMP mostró que existe una gran dependencia de la MS disponible expresada en $\mathrm{kg} \mathrm{MS} \mathrm{ha}^{-1}$ in función de la AC con un alto nivel de precisión. Dado el nivel de exactitud de la ecuación de regresión desarrollada en este estudio $\left(R^{2}=0,85\right)$, el PMP pude ser una herramienta útil para estimar la MSA a nivel de campo para praderas mixtas compuestas por L. perenne y C. clandestinus.

Palabras clave: Regresión lineal, materia seca acumulada, altura comprimida, forraje disponible. 


\section{INTRODUCTION}

The use of grassland as a food resource is governed by different utilization criteria in order to determine the optimal time to start defoliation. Some of these criteria are based on resting days, grassland height, leaf area index, accumulated herbage mass (AHM) expressed as available dry matter $(\mathrm{kg} \mathrm{DM} \mathrm{ha-1})$, number of leaves per steam, among others (Solomon et al., 2017). The grassland uses without a determined criterion leads to mistakes in terms of animal response and at the grassland level. When the grassland is defoliated more frequently, forage production can be affected, generating smaller plants with a low photosynthetic capacity; on the other hand, when the grassland is defoliated sporadically, there is a vegetative material loss due to senescence at the leaves (Balocchi et al., 2011; Calvache et al., 2020).

In Colombia, and in countries like Chile, Argentina, New Zealand and Southern Australia, milk production systems depend on pasture as their forage base and must be precise in their grazing schedules in order to optimize forage production (Hemme et al., 2014). One of the most important objectives in Colombian milk production systems is to produce milk efficiently by increasing output, reducing costs and preserving compositional quality (Carallua and Ortega, 2016). Thus, grazing plays an important role given that is the most economical food resource considering its production volume (Keim et al., 2015). A good understanding of the dynamic growth cycle, nutritional value and AHM capacity of grasslands is essential to manage them efficiently. In Colombia, these values are calculated based on the number of days between defoliations, but the climatic conditions that influence plant growth and regrowth are not considered (Sándor et al., 2018). When pastures are not able to adequately recover from grazing, quality and quantity of forage is reduced, resulting in physical, technical and economic difficulties in milk production systems.

In general, grassland growth is dynamic, constant and irreversible (Herz et al., 2017), making it a food that is constantly available if environmental conditions arise. Loaiza et al. (2017) stated that a success in defoliation frequency relies on giving the prairie enough time to recover; this implies that grazing criteria should be precise enough as to allow the pasture to accumulate enough reserve water-soluble carbohydrates in order to be prepared for the next grazing and at the same time meet the fundamental objective of providing the greatest amount of nutrients to the animal. There are different methods to estimate the optimal defoliation frequency, which vary from calendar days up to satellite images (Pullanagari et al., 2018), including the use of thermal time (Calvache et al., 2020) and the rising plate meter (RPM); some being more precise than others. Regardless of the method used, the estimation of dry matter availability must be quick and reliable, since intensive grazing management needs immediate information for quick decision making. Accordingly, the RPM is the most commonly used method in countries like Chile and New Zealand (Beltran et al., 2019; Piña et al., 2020).

Nevertheless, the use of this method requires a previous calibration under the conditions where it will be used, given that the standard equations of this instrument were obtained in countries where this technology was developed, which makes the prediction of AHM in the Colombian production systems inaccurate, since the pasture behavior is directly related to the climatic, edaphic and management conditions of the prairie (Ansquer et al., 2009).

The objective of this study was to develop the RPM calibration equation, which allows Colombian producers who use mixed pastures of L. perenne and C. clandestinus to quickly and accurately predict the availability of dry matter and thus schedule grazing.

\section{MATERIALS AND METHODS}

\section{Experimental site}

The experiment was carried out at the San Pedro farm $\left(4^{\circ} 48^{\prime} 34^{\prime \prime} \mathrm{N} ; 7^{\circ} 06^{\prime} 09^{\prime \prime} \mathrm{W}\right)$, located in the municipality of Cota, at 2548 m.a.s.l. Climatic information including Koppen-Geiger classification, mean annual temperature of $13^{\circ} \mathrm{C}$ and accumulated annual precipitation of $900 \mathrm{~mm}$, with two cycles of rain (bimodal), concentrating rainfall during the months of February to May, and August to November. The experiment was conducted between December of 2013 and February of 2014, during the summer season. The site was located on a flat topography with a slope less than $2 \%$. Soil properties measured at the beginning of the experiment included a $\mathrm{pH}$ of 5.3 , and contained $0.78 \mathrm{~g} \mathrm{~kg}^{-1}$ of organic matter, $11.9 \mathrm{mg} \mathrm{kg}^{-1}$ of P-Olsen, and $4.3 \%$ aluminum saturation.

\section{Experimental and sampling design}

The paddocks were composed of 30\% ryegrass (Lolium perenne L.) and 70\% Kikuyo grass (Cenchrus clandestinus Hochst. ex Chiov.), with two years of establishment and destined to grazing Holstein dairy cattle. Grazing is rotational in strips with an occupation period of 3 to 5 days and a resting period between 40 and 50 days depending on 
the dairy platform. The farm had an occupation period for each paddock that varied from 3 to 5 days and a rest period from 40 to 50 days. During sampling period, the occupation time was 3 days and the resting period was 45 days.

Seven hectares destined for the dairy platform and distributed in 16 paddocks were used. Sampling started eight days after grazing, and all the paddocks were then sampled on a daily basis until the subsequent grazing period.

\section{Data collection}

A double sampling method was used, which consisted of a $0.25 \mathrm{~m}^{2}$ frame that was randomly launched and where the frame fell, the compressed height $(\mathrm{CH})$ measurement was made with the Rising Plate Meter (One reading of an electronic RPM is $36 \mathrm{~cm}$ diameter, $315 \mathrm{~g}$ plate weight; FARMWORKS Ltd®., Feilding, New Zealand), after that, with the traditional clipping method the vegetative material corresponding to the place where the measurement was made with the RPM was clipped at ground level. The fresh sample was weighed with a $0.1 \mathrm{~g}$ precision digital scale. All samples were properly labeled with the paddock number, day and the corresponding $\mathrm{CH}$; subsequently, they were refrigerated in a cooler to keep them at a temperature of 3 to $4^{\circ} \mathrm{C}$ while they were transferred to the Animal Nutrition Laboratory of the Universidad de La Salle, to determine dry matter content (AOAC, 2010). In total, 1,650 samples corresponding to the 16 paddocks were taken during 33 days of sampling; 825 measurements corresponded to the RPM and 825 to the clipping method. The sampling started when the pastures had 8 days of regrowth and it continued every day until pastures had 40 days of regrowth. The 8 day was the day 0 for the sampling.

\section{Statistical analysis}

A linear regression analysis was used to estimate the parameters of the model that relates the $\mathrm{CH}$ versus accumulated herbage mass (AHM) expressed in $\mathrm{kg} \mathrm{DM} \mathrm{ha}^{-1}$. The intercept and slope were determined as the rate of change in terms of $\mathrm{kg} \mathrm{DM} \mathrm{ha-1}$ per $\mathrm{cm}$ of $\mathrm{CH}$. The coefficient of determination $\left(R^{2}\right)$ and root mean square error (RMSE) were used as goodness of fit test.

The model used was the following: [Equation 1] Simple linear regression model

$$
Y_{t}=\beta_{0}+\beta_{1} x_{i}+\varepsilon_{i} \quad i=1,2, \ldots, \mathrm{N}
$$

where:

$Y_{t}=$ dependent variable (AHM expressed like $\mathrm{kg}$ $\mathrm{DM} \mathrm{ha}^{-1}$;

$\beta_{0}=$ the "constant" intercept; $\beta_{1}=$ the slop "parameters" of the independent variable;

$x_{i}=$ independent variables $(\mathrm{CH}$ expressed in $\mathrm{cm})$;

$\varepsilon_{i}=$ random experimental error

\section{Model validation}

Models were validated according to accuracy, which was the average distance between each point and the equivalent line as a measure in the approximation of the average between observed and predicted data.

[Equation 2] $\quad A f=10^{\sum\left[\log \left(\frac{x_{P}}{x_{b}}\right)\right] / n}$

where $X_{p}=$ value of the specific maximum predictive $\mathrm{AHM}\left({ }^{\circ} \mathrm{C}^{-1}\right), X_{b}=$ value of the maximum specific observed AHM $\left({ }^{\circ} \mathrm{C}^{-1}\right), \mathrm{n}=$ number of observations, and $A f=$ the accuracy value in the prediction.

The dataset used for the validation of the models was obtained from the samples collected in the same experimental plots. This dataset was used in the development of the models, so that the models could be cross-validated by evaluating the percent variation in the data that could be explained by the model (Chuine et al., 1999; Fan et al., 2018). The $R^{2}$ and RMSE were developed using the minimum squares (Karimi et al., 2018). All data were analyzed using the adjusted model PROC REG in SAS V9.0 (SAS Institute, Cary, NC, USA).

\section{RESULTS AND DISCUSSION}

\section{Calibration equation}

The regression analysis assumes a linear model, which explains the dependence of AHM on the $\mathrm{CH}$, obtaining a prediction equation for $\mathrm{AHM}$ in function of $\mathrm{CH}$. Table 1 shows the results obtained for the regression parameters by the least squares method.

The following equation describes the relation between the AHM $(\mathrm{kg} \mathrm{DM} \mathrm{ha-1)}$ and $\mathrm{CH}(\mathrm{cm})$.

[Equation 1.1] $Y=79.7 x+319.7$

So that, in mixed pastures composed of $30 \%$ L. perenne and $70 \%$ C. clandestinus, the resulting RPM calibration equation that estimate AHM availability is expressed as follows:

[Equation 1.2] $\quad \mathrm{kg} \mathrm{DM} \mathrm{ha}^{-1}=79.7 \times(\mathrm{CH})+319.7$ $\mathrm{CH}=$ Compressed height $(\mathrm{cm})$

The simple linear regression is a model that fit to predict the AHM in $\mathrm{CH}$ function. In fact, this is the most commonly used model for RPM calibration tests in different forage species (Michell, 1982; Michell and Large, 1983; Van der Colf, et al., 2013; Nakagami, 2016; Harmse et al., 2019; Cho, et al., 2019; Rayburn, 2020). Dillard et 
Table 1. Regression parameters (intercept and slope), least squares and standard error developed for the prediction equation of the rising plate meter.

\begin{tabular}{lcc}
\hline Parameter & Least squares & Standard error \\
\hline$\beta_{0}$ & 319.663 & 13.124 \\
$\beta_{1}$ & 79.705 & 0.616 \\
\hline
\end{tabular}

$\beta_{0}:$ intercept; $\beta_{1}$ : slope.

al. (2016) evaluated the performance of the RPM in multispecies pastures composed of grasses, legumes and weeds, and reported that even, when equating the intercept to 0 , the best prediction equation is a linear regression. The value of the slope reported for this experiment was 79.7, which means that for each centimeter of $\mathrm{CH}$ that the RPM measures the AHM is $79.7 \mathrm{~kg} \mathrm{ha}^{-1}$. This slope value is lower than those reported by Canseco et al. (2007), at the FIA Project research developed in Chile concerning to grazing management at different seasons of the year, finding that for Lolium perennial prairies in winter, spring, summer and autumn, the slope values were 95, 100, 160 and 120 , respectively. This shows that the rate of change for each height centimeter of the RPM measures is lower for mixed meadows composed of L. perenne and C. clandestinum, which can be explained by the fact that the RPM calibration is being carried out for grasses with different growth habits (Gastal and Lemaire, 2015; Escobar et al., 2020). Some studies that calibrated the RPM calling it Disc Pasture Meter (DPM) in highly fibrous grasslands such as Stipagrostis amabilis found that the slope for this type of species is approximately twice than the used for L. perenne and mixed grasslands (Harmse, et al., 2019). On the other hand, Nakagami, (2016) reported slopes that vary between 10 and $20 \mathrm{~kg}$ DM ha ${ }^{-1}$ depending on the species sampled.

The intercept reference reached 319.6, which was lower than the values reported by Canseco et al. (2007) for winter and spring (400), but higher for the summer (250) and autumn (350). This shows that in monophytic grasslands of Lolium perenne, the height of post-grazing residue varies throughout the year and adapts to the grazing system. The equation generated by the manufacturer of the RPM presents a slope of 158 and an intercept of 200, estimating a greater amount of available DM ha-1 regarding to this study. This could be due to the fact that New Zealand established prairies have a higher stubble density and are mostly monophytic, composed of Lolium perenne, explaining why at the same $\mathrm{CH}$ there is a greater DM availability per hectare. However, the slope and intercept values reported in the present study, as well as the references used, agree with those reported by Moreno et al. (2019), who assure that in Pennisetum clandestinum
Hochst.Ex Chiov grasslands the intercept is 2978.9 and the slope 249.52 , which is excessively high for this type of grassland.

The values obtained for both $R^{2}$ and RMSE (Table 2) indicate that there is a high degree of association between the dependent and the independent variable, which agrees with the range of values that vary from 0.5 up to 0.8 for $R^{2}$ reported by Van der Colf et al. (2013), in their studies about calibration of this type of methodologies in kikuyu (Pennisetum clandestinum) over-sown with ryegrass (Lolium spp.). Most of the studies that develop calibration equations for this type of technology report a $R^{2}$ above 0.7 , indicating that regardless of the forage species, the RPM is a suitable technology to be used in the field (Higgins et al., 2019).

The values of the regression equation developed by Canseco et al. (2007) show DM availabilities per hectare of 1200, 1400, 2000, 2400, 3000,3600 and 4200, for $\mathrm{CH}$ of $8,10,16,20,26,32$ and 38 , respectively, presenting a difference of $243,283,405,486,608,730$ and 852 , with respect to the equation obtained in the present study at the same heights (Table 3). The difference between the equations is reliable when linked to the type and structure of the grasslands. In the present study, there was a mixed grass with a lower density and number of stubble per unit area compared to a monophytic grasses composed only of Lolium perenne. In addition, the management to which the grasses are subjected affects its growth habits (Parga, 2003). The difference in dry matter availability per hectare in New Zealand regarding to countries like Chile and Colombia is mainly due to grazing management, species and fertilization management, which leads to higher grass density, resulting in a greater number of stubbles per square meter (Poff et al., 2011).

The results obtained in the measurements with the traditional field clipping presented a difference

Table 2. Test and accuracy parameters for the regression model

\begin{tabular}{lc}
\hline Test & Value \\
\hline$R^{2}$ & 0.85 \\
RMSE & 0.53 \\
\hline
\end{tabular}

$R^{2}$ : coefficient of determination; RMSE: root mean square error. 
in average of $25.64 \mathrm{~kg} \mathrm{DM} \mathrm{ha}^{-1}$, with respect to those obtained by the RPM (Table 3). This is due to the fact that the calibration equation for the RPM accurately adjusts the cumulative DM values. A similar trend was observed by Nakagami and Itano (2014), and Rayburn (2020), indicating that there is a strong relationship between the AHM estimated with the RPM and the DM yield estimated by the clipping technique. Estrada (2002), Bernal (2008) and Vela and Roncancio (2009) reported that values from 2400 and $2600 \mathrm{~kg}$ DM ha ${ }^{-1}$ with 35 days of regrowth, presented a difference of $67 \mathrm{~kg}$ DM ha ${ }^{-1}$ with respect to those found in the present study at 35 days but using the RPM.

\section{Model validation}

Regarding the analysis of studentized residuals vs predicted values (Fig 1), it can be observed that the assumptions of the linear regression model are accepted because the cloud point does not present a clear shape or a trend, showing that the residuals are randomly distributed around a zero value and the homoscedasticity assumptions are accepted for the RPM calibration equation. Besides, there is a close relationship between the observed and predicted data, which demonstrates the dependence of AHM in function of the $\mathrm{CH}$ (Fig. 2).

Table 3. Accumulated herbage mass ( $\left.\mathrm{kg} \mathrm{DM} \mathrm{ha}^{-1}\right)$ at different compressed heights measured with two different methodologies.

\begin{tabular}{ccc}
\hline Compressed height $(\mathbf{c m})^{+}$ & Rising plate meter* & Clipping \\
\hline 6 & 798 & 852 \\
8 & 957 & 1050 \\
10 & 1117 & 1119 \\
12 & 1276 & 1258 \\
14 & 1436 & 1460 \\
16 & 1595 & 1566 \\
18 & 1754 & 1736 \\
20 & 1914 & 1959 \\
22 & 2073 & 2047 \\
24 & 2233 & 2226 \\
26 & 2392 & 2353 \\
28 & 2551 & 2559 \\
30 & 2711 & 2739 \\
32 & 2870 & 2849 \\
34 & 3030 & 2964
\end{tabular}

${ }^{+}$: Compressed height measured with the RPM. *: estimated from the calibration equation.

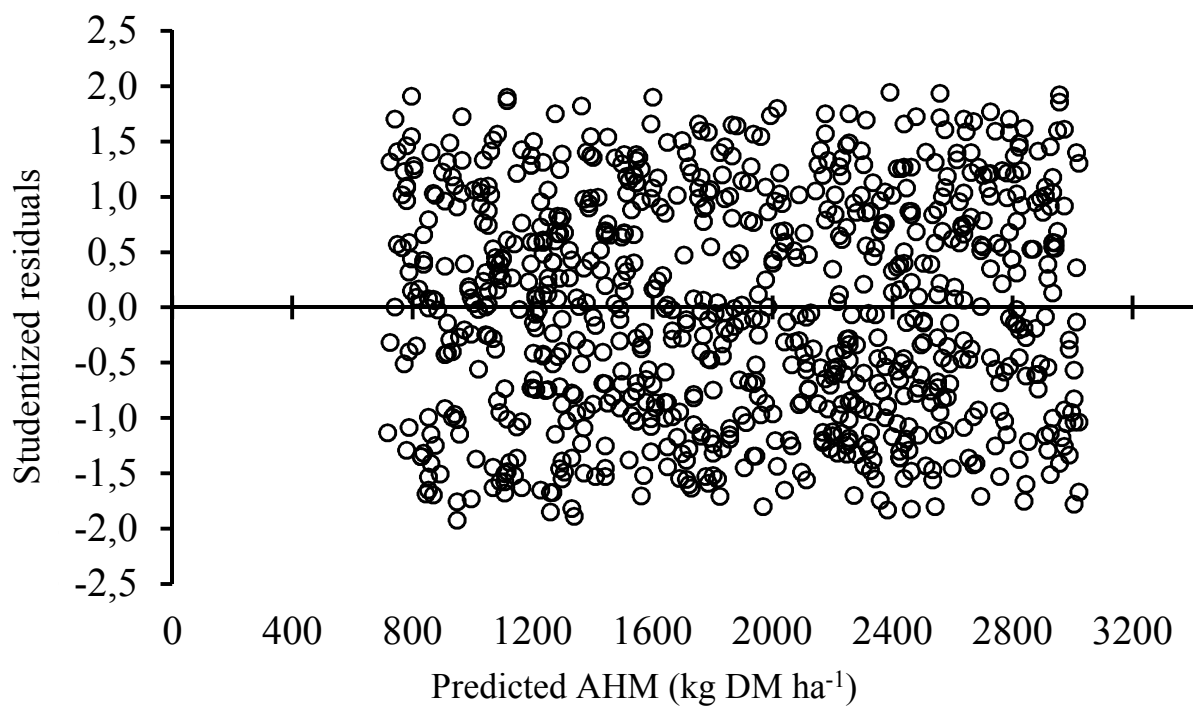

Fig. 1. Studentized residuals vs. accumulated herbage mass predicted using RPM. 


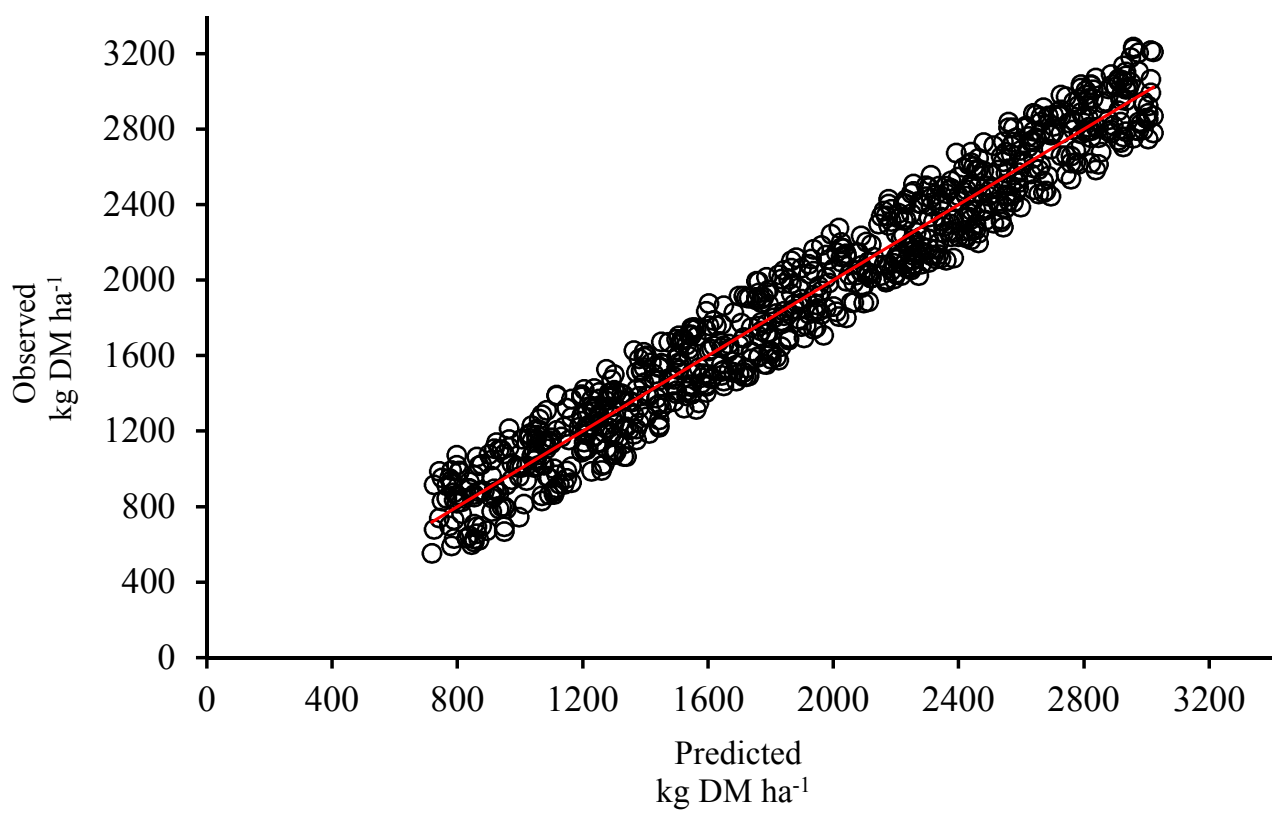

Fig. 2. Relationship between observed vs. predicted value for accumulated herbage mass (kg DM $\left.\mathrm{ha}^{-1}\right)$ when it is a linear function of compressed height.

$P<0.0001 ; \mathrm{RSq}=0.99 ; \mathrm{RMSE}=0.02$

\section{CONCLUSIONS}

This study allowed the development of a highly accurate RPM calibration equation to estimate AHM in mixed grasslands composed of $30 \%$ Lolium perenne and 70\% Pennisetum clandestinum in Colombian high tropical conditions during the summer season. Therefore, further research is required to develop appropriate equations for a wider range of species and environments.

\section{ACKNOWLEDGEMENTS}

We would like to thank the Universidad de La Salle, Bogotá, Colombia, for allowing us to use the RPM for this research.

\section{LITERATURE CITED}

Ansquer, P., R. Al Haj Khaled, P. Cruz, J.P. Theau, O. Therond, and M. Duru. 2009. Characterizing and predicting plant phenology in species-rich grasslands. Grass and Forage Science 64:57-70.

AOAC. 2010. Method 990.03: Protein (crude) in animal feed: Combustion method. Official Methods of Analysis. 18th ed. Association of Analytical Chemist Int. (AOAC), Gaithersburg, Maryland, USA.
Balocchi, O., C. Solis, and J. Poff. 2011. Filocrono en una pradera de Lolium perenne L.: Efecto de la frecuencia de defoliación y fertilización nitrogenada. Agro Sur 39:165-176.

Beltran, I.E., P. Morales, O.A. Balocchi, y R. Pulido. 2019. Interaction between herbage mass and time of herbage allocation modify milk production, grazing behaviour and nitrogen partitioning of dairy cows. Animal Production Science 59(10):1837-1846.

Bernal, J. 2008. Pastos y Forrajes Tropicales. Manejo de Praderas. Tomo 1. $5^{\mathrm{a}}$ ed. 702 p. Ángel Agro - Ideagro, Bogotá, Colombia.

Calvache, I., O. Balocchi, M. Alonso, J.P. Keim, and I.F. López. 2020. Thermal time as a parameter to determine optimal defoliation frequency of perennial ryegrass (Lolium perenne L.) and pasture brome (Bromus valdivianus Phil.). Agronomy 10.

Canseco, C., R. Demanet, O. Balocchi, J. Parga, V. Anwandter, A. Abarzúa, et al. 2007. Determinación de la disponibilidad de materia seca de praderas en pastoreo. p. 23-49. Manejo del Pastoreo. Instituto de Investigaciones Agropecuarias INIA, Universidad Austral de Chile, Universidad de La Frontera, Fundación para la Innovación Agraria, Cooprinsem, Osorno, Chile. 
Carulla, J., y E. Ortega. 2016. Sistemas de producción lechera en Colombia: Retos y oportunidades. Archivos Latinoamericanos de Producción Animal 24(2):83-87.

Cho, W., B.W. Brorsen, J.T. Biermacher, and J.K. Rogers. 2019. Rising plate meter calibrations for forage mass of wheat and rye. Agricultural \& Environmental Letters 4:1-4.

Chuine, I., O. Cour, and D. Rousseau. 1999. Selecting models to predict the timing of flowering of temperate trees: implications for tree phenology modelling. Plant, Cell \& Environment 22:1-13.

Dillard, S.L., A.N. Hafla, M.D. Rubano, R.C. Stout, A.F. Brito, and K.J. Soder. 2016. Evaluation of a rising plate meter for use in multispecies swards. Agricultural \& Environmental Letters 1:1-4.

Escobar, M.A., E.A. Cardenas, and J.E. Carulla. 2020. Effect of altitude and defoliation frequency in the quality and growth of kikuyu grass (Cenchrus clandestinus). Revista Facultad Nacional de Agronomía Medellín 73:9121-9130.

Estrada, J. 2002. Pastos y Forrajes para el Trópico Colombiano. 1a․ ed. 511 p. Facultad de Ciencias Agropecuarias, Universidad de Caldas, Editorial Universidad de Caldas, Manizales, Colombia.

Fan, X., K. Kawamura, W. Guo, T.D. Xuan, J. Lim, N. Yuba, et al. 2018. A simple visible and near-infrared (V-NIR) camera system for monitoring the leaf area index and growth stage of Italian ryegrass. Computers and Electronics in Agriculture 144:314-323.

Gastal, F., and G. Lemaire. 2015. Defoliation, shoot plasticity, sward structure and herbage utilization in pasture: Review of the underlying ecophysiological processes. Agriculture 5:1146-1171.

Harmse, C.J., N. Dreber, and W.S.W. Trollope. 2019. Disc pasture meter calibration to estimate grass biomass production in the arid dunefield of the south-western Kalahari. African Journal of Range \& Forage Science 36:161-164.

Hemme, T., M.M. Uddin, and A. Ndambi. 2014. Benchmarking cost of milk production in 46 countries. Journal of Reviews on Global Economics 3:254 -270.

Herz, K., S. Dietz, S. Haider, U. Jandt, D. Scheel, and H. Bruelheide. 2017. Predicting individual plant performance in grasslands. Ecology and Evolution 7(21):8958-8965.
Higgins, S., J. Schellberg, and J.S. Bailey. 2019. Improving productivity and increasing the efficiency of soil nutrient management on grassland farms in the UK and Ireland using precision agriculture technology. European Journal of Agronomy 106:67-74.

Karimi, S., A.A. Sadraddini, A.H. Nazemi, T. Xu, and A.F. Fard. 2018. Generalizability of gene expression programming and random forest methodologies in estimating cropland and grassland leaf area index. Computers and Electronics in Agriculture 144:232-240.

Keim, J.P., I.F. López, and O.A. Balocchi. 2015. Sward herbage accumulation and nutritive value as affected by pasture renovation strategy. Grass and Forage Science 70:283-295.

Loaiza, P. A., O. Balocchi, and A. Bertrand. 2017. Carbohydrate and crude protein fractions in perennial ryegrass as affected by defoliation frequency and nitrogen application rate. Grass and Forage Science 72:556-567.

Michell, P. 1982. Value of rising-plate meter for estimating herbage mass of grazed perennial ryegrass-white clovers swards. Grass and Forage Science 37:81-87.

Michell, P., and R.V. Large. 1983. The estimation of herbage mass of perennial ryegrass swards: a comparative evaluation of a rising-plate meter and a single-probe capacitance meter calibrated at and above ground level. Grass and Forage Science 38:295-299.

Moreno, D., C. Fonseca, C.E. Rodríguez-Molano, and N.J. Pulido-Suarez. 2019. Calibration of rising plate meter in prairie kikuyo grass (Pennisetum clandestinum Hochst. Ex Chiov) in the high Colombian tropics. Ciencia y Agricultura 16:52-62.

Nakagami K., and S. Itano. 2014. Improving pooled calibration of a rising-plate meter for estimating herbage mass over a season in cool-season grass pasture. Grass Forage Science 69:717-723.

Nakagami, K. 2016. Effects of sites and years on the coefficients of rising plate meter calibration under varying coefficient models. Grassland Science 62:128-132.

Parga, J. 2003. Utilización de praderas y manejo de pastoreo con vacas lecheras. Seminario: Hagamos de la lechería un mejor negocio. p. 24-40. Serie Actas $\mathrm{N}^{\circ}$ 24. Instituto de Investigaciones Agropecuarias INIA Remehue, Osorno, Chile.

Piña, L.F., O. Balocchi, J.P. Keim, R.G. Pulido, and F. Rosas. 2020. Pre-grazing herbage mass affects grazing behavior, herbage disappearance, and the residual nutritive value of a pasture during the first grazing session. Animals (Basel) 10. 
Poff, J.A., O. Balocchi, and I.F. López. 2011. Sward and tiller growth dynamics of Lolium perenne L. as affected by defoliation frequency during autumn. Crop and Pasture Science 62(4):346-354.

Pullanagari, R., G. Kereszturi, and I. Yule. 2018. Integrating airborne hyperspectral, topographic, and soil data for estimating pasture quality using recursive feature elimination with random forest regression. Remote Sensing 10.

Rayburn, E. 2020. Plate meter calibrations for forage mass follow a continuum of sward basal density. Crop, Forage \& Turfgrass Management 6(1):e20009.

Sándor, R., C. Picon-Cochard, R. Martin, F. Louault, K. Klumpp, D. Borras, et al. 2018. Plant acclimation to temperature: developments in the pasture simulation model. Field Crops Research 222:238-255.
Solomon, J.K.Q., B. Macoon, and D.J. Lang. 2017. Harvest management based on leaf stage of a tetraploid vs. a diploid cultivar of annual ryegrass. Grass and Forage Science 72:743756.

Van der Colf, J., P. Botha, R. Meeske, and W. Truter. 2013. Calibration of the rising plate meter for pasture yield determine. p. 873. In the 22nd International Grassland Congress (Revitalising Grasslands to Sustain Our Communities). 15-19 September. Sydney, Australia.

Vela, J., and M. Roncancio. 2009. Caracterización de la dinámica de producción de materia seca del kikuyo (Pennisetum cladestinum) asociado con árboles y en pastoreo para producción de leche en el trópico alto colombiano. Revista de Ciencia Animal 2:2740. 